\title{
Distribution of Genetic Polymorphism in the CCR5 among Caucasians, Asians and Africans: A Systematic Review and Meta-Analysis
}

\author{
Beatrice A. Ongadi1,2, George Obiero', Raphael W. Lihana ${ }^{3}$, John N. Kiiru² \\ ${ }^{1}$ Centre for Biotechnology and Bioinformatics, University of Nairobi, Nairobi, Kenya \\ ${ }^{2}$ Centre for Microbiology Research, Nairobi, Kenya \\ ${ }^{3}$ Centre for Virus Research, Kenya Medical Research Institute, Nairobi, Kenya \\ Email: bongadi@kemri.org
}

How to cite this paper: Ongadi, B.A., Obiero, G., Lihana, R.W. and Kiiru, J.N. (2018) Distribution of Genetic Polymorphism in the CCR5 among Caucasians, Asians and Africans: A Systematic Review and Meta-Analysis. Open Journal of Genetics, 8 , 54-66.

https://doi.org/10.4236/ojgen.2018.83006

Received: July 18, 2018

Accepted: September 11, 2018

Published: September 14, 2018

Copyright (ㅇ 2018 by authors and Scientific Research Publishing Inc. This work is licensed under the Creative Commons Attribution International License (CC BY 4.0).

http://creativecommons.org/licenses/by/4.0/

\begin{abstract}
Background: Cysteine-Cysteine Chemokine Receptor 5 (CCR5), also referred to as CD195, is a component of the mammalian cell membrane and is receptor for chemokines that are activated during cell damage and inflammations. This receptor is coded by a gene located in the human chromosome 3. A Mutation on this CCR5 through deletion of 32 base pairs results into a non-destructive gene CCR $5 \Delta 32$. It enables protection against HIV infection to its homozygous carriers and slows progression of the disease to heterozygous carriers. Objective: To systematically review and establish global distribution of CCR $5 \Delta 32$ allele in HIV-1 infected individuals over the history of the epidemic and compare regions inhabited by Caucasians, Asians and Africans. Methodology: This meta-analysis comprised of published papers with over 10,000 individuals from whom CCR5-Delta 32 allele was successfully genotyped and recorded. The study review period was from 1984 to 2017. The search targeted online sources such as Hinari specifically PubMed Central, Google scholar, Science Direct, Research4Life, National Center for Biotechnology Information (NCBI), OVID databases, AIDS Journal and Google. The searches were not limited to a particular publication language or study design but excluded letters of correspondence and conference presentations. Search strategy using key words from a combination of Medical Subject Heading $(\mathrm{MeSH})$ and free text including terms related to CCR5, CCR5 $\Delta 32$ and HIV were performed in Medical Literature Analysis and Retrieval System Online (MEDLINE) through Ovid Open Access. Additional studies were identified by perusing the reference list of relevant and included articles. The review considered studies conducted among general population, both HIV positive and HIV negative individuals, exposed seronegatives (ESN), exposed seropositives (ESP) and highly exposed seronegatives (HESN) and resultant data
\end{abstract}


pooled using a fixed effect model. Results: A total of 40 studies comprising 10,871 participants were reviewed. These were from three main regions: Europe, Africa and Asia. Of the studies accessed and reviewed, Caucasians were $22.5 \%$, Africans were 12.5\%, Europeans were $27 \%$ and others (not specified) were $37.5 \%$. The distribution of CCR $5 \Delta 32$ allele among different populations in comparison to its heterozygosity displayed significant association with a pooled Odds Ratio (OR) of 0.08 (95\% CI, $0.03-0.18, \mathrm{P}<0.00001$ ), test of subgroup differences at $\mathrm{I}^{2}=0 \%$ and a $\mathrm{P}$ value of 0.50 . Among the Caucasians alone the OR was at $0.04\left(95 \% \mathrm{CI}, 0.01-0.19, \mathrm{I}^{2}=96 \%\right)$ and a significant $\mathrm{P}$ value of $<0.00001$ displaying a high presence of CCR5 $\Delta 32$ homozygosity as compared to Europeans with OR of 0.09 (95\% CI, $0.04-0.19, \mathrm{I}^{2}=21 \%, \mathrm{P}=$ 0.25 ) and Africans with OR 0.25 (95\% CI, $\left.0.03-2.29, \mathrm{I}^{2}=0 \%, \mathrm{P}=0.81\right)$; an indication that race can be a factor that determines CCR $5 \Delta 32$ homozygosity or heterozygosity and it highly favors the Caucasians. Out of 136 homozygous carriers found in the review Europeans had 6\%, Caucasian 93\%, Africans $0 \%$ and others combined $0.7 \%$. Conclusion: The distribution of CCR $5 \Delta 32$, an allele that is associated with lower acquisition of HIV/AIDS is at $93 \%$ among the Caucasians. The remaining $7 \%$ is shared amongst the rest of the populations, hence high susceptibility to the disease. Minimal availability of recorded data experienced in this study is a clear indication that there exist major gaps in studies that could further associate CCR5 $\Delta 32$ allele frequency and HIV infection in different populations. The review recommends a mixture of population genetics and epidemiological studies in trying to understand the increasing rates of HIV prevalence among selected groups.

\section{Keywords}

CCR5, CCR5 $\Delta 32$, HIV, Genetic Polymorphism, Allele Frequency

\section{Introduction}

Mammalian cell membranes have cysteine-cysteine chemokine receptor 5 (CCR5) as a component. They are also referred to as CD195 and are popularly known for allowing in chemokines that signal cellular response during inflammation and after cellular damages [1]. The receptor (CCR5) is coded by a gene located in the human chromosome 3. Several known mutations of CCR5 result into damage of the expressed receptor either by deletion, insertion and or omission. The CCR5-Delta 32 (CCR5 $\Delta 32)$ is a damage resulting from a deletion of 32 base pairs of the CCR5 gene but the mutation is non-deleterious. This is unlike other genes that cause serious and harmful damages such as sickle cell anemia, cystic fibrosis, diabetes when knocked out. CCR5 $\Delta 32$ mutation is suspected to confer various advantages to the host in relationship to HIV acquisition [2]. Previous studies have shown that individuals having homozygosity in CCR5 $\Delta 32$ are hindered from HIV acquisitions while their heterozygous counterparts are slow progressers of the disease [3].

In human, the distribution of CCR $5 \Delta 32$ has a high geographical variation 
indicating adaptive traits and the co-evolution of HIV and the human genome [4]. This mutation results into a shortened protein that cannot be expressed on the surface hence giving a perceived resistance to HIV-1 infection, which in turn hinders faster progression to AIDS among infected persons [5].

Population genetic surveys earlier estimated the existence of CCR $5 \Delta 32$ allele among the Europeans at $10 \%$ while it was found missing among the black populace except African Americans who descended from admixture with Europeans [1] [2] [6]. The estimates were reached upon studying equally minimal samples of 747 non-European individuals against 4000 European or Caucasian [6].

A meta-analysis on the accrued data on the distribution of CCR5 $\Delta 32$ allele covering the critical HIV study period would help in generating statistics for advising on the best method to counter the spread of HIV across different populations. It would further assist in formulating a much better way of channeling prevention and treatment strategies taking into consideration current frequent travels across the globe and possible cross infections and gene flow among travelers.

\section{Materials and Methods}

\subsection{Search Criteria and Study Selection}

We searched available online sources such as Hinari specifically PubMed Central, English database of Google scholar, Science Direct, Research4Life, National Center for Biotechnology Information (NCBI), OVID databases, AIDS Journal and Google. The period of search was tailored to range from 1984 to 2017, however other relevant papers that were published before 1984 and after 2017 were enlisted to boost on literature review. Suitable published papers were identified and assembled using Mendeley desktop application. Search strategy using key words from a combination of Medical Subject Heading (MeSH) and free text including terms related to CCR5, CCR5 $\Delta 32$ and HIV were performed in Medical Literature Analysis and Retrieval System Online (MEDLINE) through Ovid Open Access. Studies conducted among the following populations were accepted for review; general population, both HIV positive and HIV negative individuals, exposed seronegatives (ESN), exposed seropositives (ESP) and highly exposed

seronegatives (HESN). To reduce reporting bias only studies with participants successfully genotyped for CCR $5 \Delta 32$ and results accurately recorded were included. The PRISMA 2009 flow diagram [7] was used to summarize details on data identification, screening and eligibility. A predetermined and comprehensive inclusion and exclusion criteria was arrived at to facilitate objective screening of different articles. Only published and original articles on the distribution of CCR $5 \Delta 32$ allele in HIV-1 infected individuals from various countries were included for the review. Letters of correspondence, papers with missing relevant data and conference presentations were excluded in this review.

\subsection{Data Abstraction and Statistical Analysis}

For accurate data abstraction, an excel sheet was used. 
Odds Ratios (OR) were used to assess the distribution of CCR5 $\Delta 32$ allele among different populations grouped as Caucasians, African, Europeans and Others. The ratio was also used to evaluate the association of CCR $5 \Delta 32$ heterozygotes and homozygotes with vulnerability to HIV infection. The Chi-square $\left(X^{2}\right)$ and $\mathrm{I}^{2}$ were used to test for the presence of, quantify and determine heterogeneity across studies [8]. P-Value of less than 0.10 was used to indicate statistical significance and publication bias accessed by a simple graphical test by Egger and Begg [9].

\section{Results}

A total of 544 relevant and non-duplicate articles were retrieved. From this, 144 articles were subjected to further analysis. The final 37 articles with 17,353 participants were accepted for inclusion in the meta-analysis (Figure 1). The search was conducted in two main phases; first a group of three reviewers independently cataloguing articles as per the agreed criteria. The result of the initial phase was cross checked by an independent reviewer to ensure an agreement accuracy of $90 \%$ and above. The second phase involved full text review and confirmation for inclusion suitability. Uncertainties and conflict of opinions were discussed and resolved in consensus by the reviewers.

Major and complete studies available for review were realized among the Caucasian population totaling to eighteen (18). The earliest study to be reviewed was conducted by Martison and group in 1997. It was done after successful characterization of the mutant allele and on realization that isolated cases of HIV positive homozygotes were still emerging. This study involved 3324 unrelated individuals from a globally distributed population and remains the largest so far in this review; studies that followed are relatively smaller and not so globally constituted. Nine studies with complete genotyped individuals were available for analysis from Asia while six studies covered Africa population and four studies under the ungrouped (others) category (Table 1). The largest share of the population reviewed were the Caucasians at $50 \%$ with a total of 52 CCR5 $\Delta 32$ Homozygotes (Figure 2).

From the forest plot, there is a clear indication that most studies reviewed and meta-analyzed were from Caucasians population (Figure 3). These studies carried a lot of weight and significance as evidenced by the size and visibility of the small squares in the plot. With heterogeneity at $62 \%$, it is observable that being a Caucasian is a factor for CCR $5 \Delta 32$ homozygosity hence it can be assumed that this is a protected population in terms of the allele. With heterogeneity at $31 \%$ being an Asian is not a sure factor for CCR $5 \Delta 32$ homozygosity hence no protection from HIV infection; few cases presenting the allele here could be as a result of gene flow or descendants of admixture with Caucasians. Scanty data was seen among the African population, out of six studies analyzed only three had events complete for estimation, others were at zero for both homozygosity and heterozygosity. Studies carried out among African population had heterogeneity of $0 \%$ 
hence being an African is clearly not a factor for CCR $5 \Delta 32$ homozygosity. The overall outcome for all the populations meta-analyzed indicates that race can be a factor that determines CCR $5 \Delta 32$ homozygosity or heterozygosity and it highly favors the Caucasians.

A correlation and a strong indication that CCR $5 \Delta 32$ homozygosity can be a shield to HIV virulence is realized from the results of the analysis for both HIV Positive and HIV negative individuals genotyped (Figure 4).

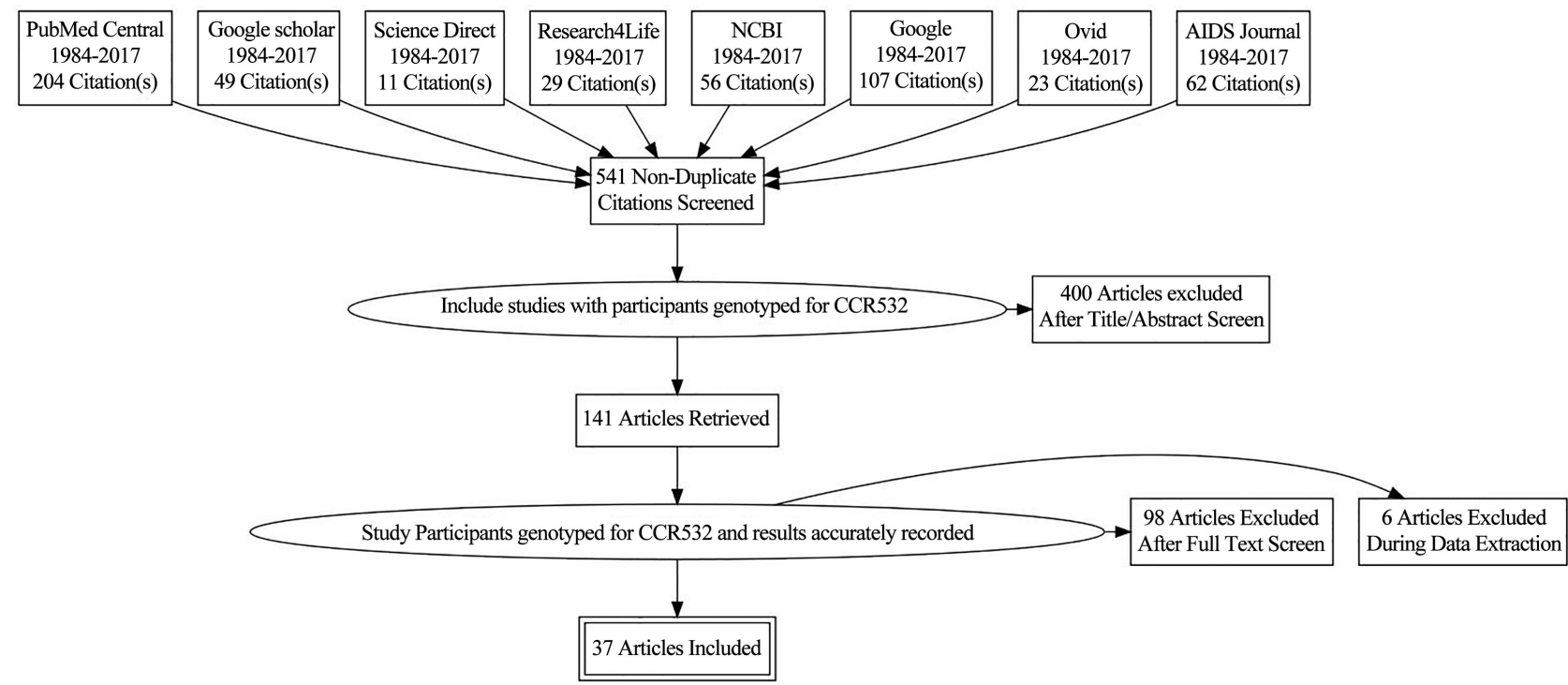

Figure 1. Summary study selection by PRISMA Flow Diagram.

Table1. Characteristics of all studies selected and grouped for review and meta-analysis (GP-General Population, SN-Seronegatives, SP-Seropositives, ESN—Exposed Seronegatives, HESN—Highly Exposed Seronegatives).

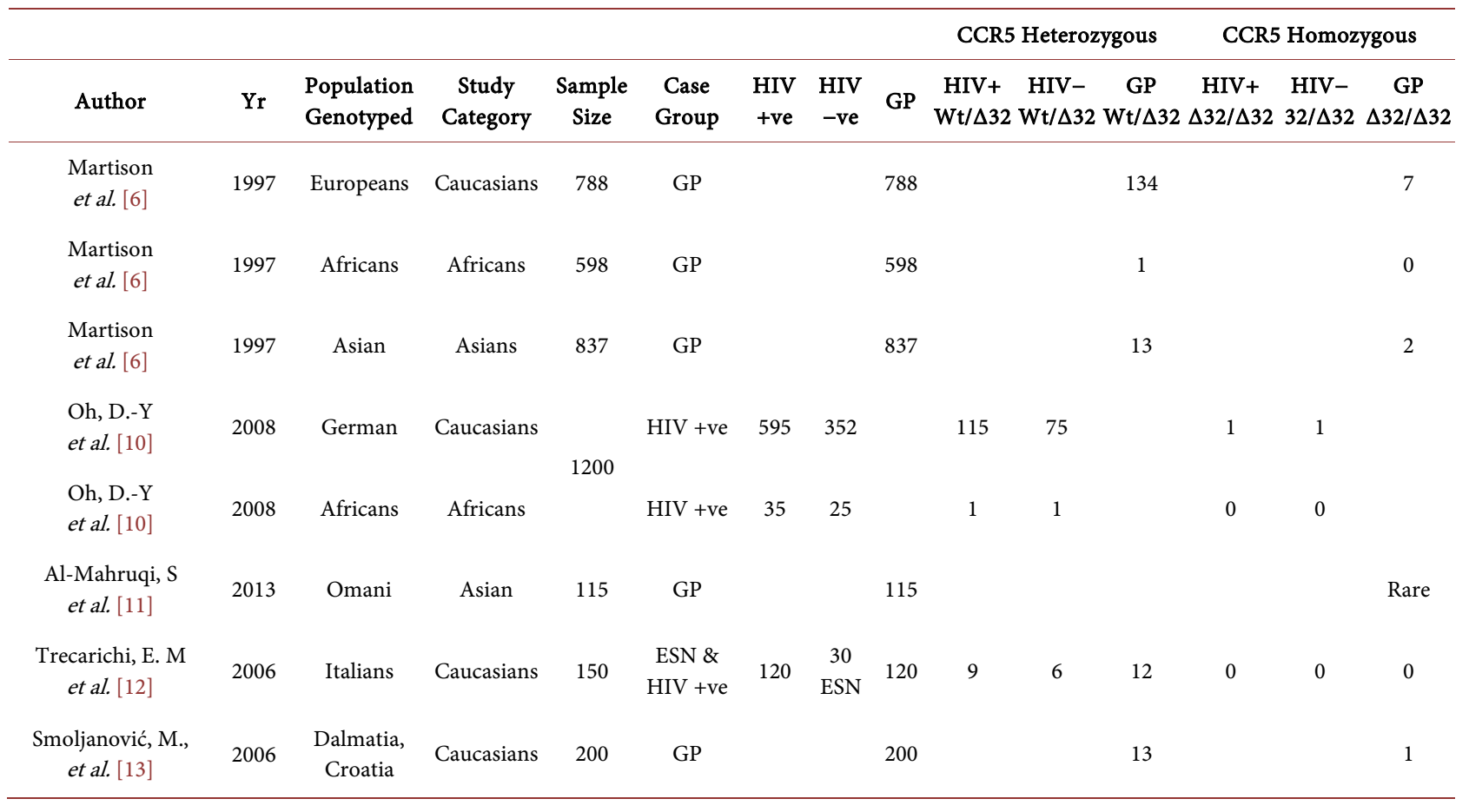




\section{Continued}

\begin{tabular}{|c|c|c|c|c|c|c|c|c|c|c|c|c|c|c|}
\hline $\begin{array}{l}\text { Lopes, M. P., } \\
\text { et al. [14] }\end{array}$ & 2014 & $\begin{array}{c}\text { Afro-Brazilia } \\
n\end{array}$ & $\begin{array}{c}\text { Other } \\
\text { Brazillian }\end{array}$ & 1042 & SCD GP & & & 1042 & & & 809 & & & 0 \\
\hline $\begin{array}{l}\text { Chavhan, A.B., } \\
\text { et al. [15] }\end{array}$ & 2013 & Indians & Asian & 108 & GP & & & 108 & & & 2 & & & 0 \\
\hline $\begin{array}{l}\text { Rahimi, H., } \\
\text { et al. [16] }\end{array}$ & 2014 & Iranian & Asian & 570 & $\begin{array}{c}\mathrm{HIV}+\& \\
-\mathrm{ve}\end{array}$ & 530 & 40 & & & 6 & & & 1 & \\
\hline $\begin{array}{l}\text { Biloglav, Z., } \\
\text { et al. [17] }\end{array}$ & 2009 & Croatia & Caucasians & 1000 & GP & & & 942 & & & & & & 95 \\
\hline $\begin{array}{l}\text { Kostrikis, L. G., } \\
\quad \text { et al. }[18]\end{array}$ & 1999 & $\begin{array}{l}\text { African- } \\
\text { Americans }\end{array}$ & Asian & 1442 & $\begin{array}{l}\text { HIV +ve } \\
\&-v e\end{array}$ & 1235 & 207 & & & 5 & & & 0 & \\
\hline $\begin{array}{l}\text { Nkenfou, C. N., } \\
\text { et al. [19] }\end{array}$ & 2013 & Cameroon & Africans & 179 & $\begin{array}{l}\text { HIV +ve } \\
\&-v e\end{array}$ & 32 & 147 & & 0 & 0 & & 0 & 0 & \\
\hline $\begin{array}{l}\text { Bharti, D., } \\
\text { et al. [20] }\end{array}$ & 2015 & India & Asian & & SN & & 200 & & & 0 & & & 0 & \\
\hline $\begin{array}{l}\text { Heydarifard, Z., } \\
\text { et al. }[21]\end{array}$ & 2017 & Iranian & Asian & 400 & $\begin{array}{l}\text { HIV +ve } \\
\&-v e\end{array}$ & 140 & 300 & & 1 & 9 & & 0 & 0 & \\
\hline $\begin{array}{l}\text { Roy, P., } \\
\text { et al. [22] }\end{array}$ & 2016 & Indians & Asian & 571 & $\begin{array}{l}\text { HIV+ } \\
\&-v e\end{array}$ & 181 & 568 & & & & & 0 & 0 & \\
\hline $\begin{array}{l}\text { Zapata,W., } \\
\text { et al. }[23]\end{array}$ & 2013 & Colombia & Caucasians & 239 & $\begin{array}{l}\text { SP and } \\
\text { HESN }\end{array}$ & 57 & 70 & 112 & & & & 0 & 0 & \\
\hline $\begin{array}{l}\text { Mehlotra, R. K., } \\
\text { et al. [24] }\end{array}$ & 2016 & $\begin{array}{l}\text { Papua New } \\
\text { Guinea }\end{array}$ & Other & 620 & GP & & & 620 & & & 0 & & & 0 \\
\hline $\begin{array}{l}\text { Corado, André de } \\
\text { Lima, et al. [25] }\end{array}$ & 2016 & Brazilian & Caucasians & 177 & HIV +ve & & 177 & & 11 & & & 0 & & \\
\hline $\begin{array}{l}\text { Angelis, Daniela } \\
\text { Souza et al. [26] }\end{array}$ & 2007 & Brazilian & Caucasians & 51 & HIV +ve & & 51 & & 2 & & & 0 & & \\
\hline $\begin{array}{l}\text { Vargas, A.E., } \\
\text { et al. }[27]\end{array}$ & 2006 & Brazilian & Caucasians & 103 & $G P$ & & & 103 & & & 7 & & & 1 \\
\hline $\begin{array}{c}\text { Carvalhaes, F } \\
\text { et al. [25] }\end{array}$ & 2005 & Brazilian & Caucasians & 249 & $\begin{array}{l}\text { Both } S P \\
\text { and } S N\end{array}$ & 110 & 139 & & 6 & 0 & & 0 & 0 & \\
\hline $\begin{array}{l}\text { Patrícia Munerato } \\
\text { et al. }[28]\end{array}$ & 2003 & Brazilian & Caucasians & 298 & HIV +ve & 183 & & 115 & 21 & & 15 & 0 & & 0 \\
\hline $\begin{array}{c}\text { Díaz, Francisco J, et } \\
\text { al. [29] }\end{array}$ & 2002 & Brazilian & Caucasians & 68 & $\begin{array}{l}\text { Both } S P \\
\text { and } S N\end{array}$ & 29 & 39 & & 1 & 1 & & 0 & 1 & \\
\hline $\begin{array}{c}\text { Pereira, Rinaldo W., } \\
\text { et al. }[30]\end{array}$ & 2000 & Brazilian & Caucasians & 907 & GP & & & 907 & & & 93 & & & 2 \\
\hline $\begin{array}{l}\text { Rugeles, María T } \\
\quad \text { et al. [31] }\end{array}$ & 2011 & Colombia & Caucasians & 65 & $\begin{array}{l}\mathrm{HIV}+\mathrm{ve} \\
\&-\mathrm{ve}\end{array}$ & 28 & 37 & & 1 & 1 & & 0 & 1 & \\
\hline $\begin{array}{l}\text { Rugeles, María T } \\
\text { et al. [31] }\end{array}$ & 2011 & Colombia & Caucasians & 80 & $\begin{array}{l}\text { HIV+ } \\
\&-v e\end{array}$ & 33 & 47 & & 3 & 2 & & 0 & 1 & \\
\hline $\begin{array}{c}\text { Nina } \\
\text { Valadez-González., } \\
\text { et al. [32] }\end{array}$ & 2011 & Mexico & Caucasians & 355 & $\begin{array}{l}\text { HIV +ve } \\
\&-\mathrm{ve}\end{array}$ & 62 & 51 & 242 & 11 & 7 & 15 & 0 & 2 & 0 \\
\hline
\end{tabular}




\section{Continued}

\begin{tabular}{|c|c|c|c|c|c|c|c|c|c|c|c|c|c|c|}
\hline $\begin{array}{l}\text { Abdel Halim Salem } \\
\text { et al. }[33]\end{array}$ & 2009 & Bahraini & Asian & 304 & HIV -ve & & 304 & & & & 15 & & & 1 \\
\hline $\begin{array}{l}\text { Yudin, N., } \\
\text { et al. [34] }\end{array}$ & 1998 & Russian & Caucasians & 531 & GP & & & 531 & & & 59 & & & 12 \\
\hline $\begin{array}{c}\text { Grigory S. Ryabov., } \\
\text { et al. }[35]\end{array}$ & 2004 & Russian & Caucasians & 171 & GP & & & 171 & & & 31 & & & 0 \\
\hline $\begin{array}{l}\text { Grace C. John, } \\
\text { et al. }[36]\end{array}$ & 2001 & Kenya & Africans & 276 & HIV +ve & 276 & & & 1 & & & 0 & & \\
\hline $\begin{array}{l}\text { Sidoti, A., } \\
\text { et al. [37] }\end{array}$ & 2005 & Sicilian & Other & 1015 & $\begin{array}{c}\text { HIV +ve } \\
\&-v e\end{array}$ & 114 & 901 & & 5 & 70 & & 0 & 5 & \\
\hline $\begin{array}{l}\text { Torimiro, J N., } \\
\text { et al. }[39]\end{array}$ & 2007 & Cameroon & Africans & 1390 & GP & & & 1390 & & & 0 & & & 0 \\
\hline $\begin{array}{l}\text { Al-Jaberi, S A,. } \\
\quad \text { et al. }[40]\end{array}$ & 2013 & Emiratis & Asian & 253 & GP & & & 253 & & & 0 & & & 0 \\
\hline $\begin{array}{l}\text { Al-Jaberi, S A,. } \\
\quad \text { et al. }[40]\end{array}$ & 2013 & Tunisians & Africans & 150 & GP & & & 150 & & & 0 & & & 0 \\
\hline Kalev, I., [41] & 2000 & Estonians & Caucasians & 504 & GP & & & 504 & & & 117 & & & 16 \\
\hline
\end{tabular}

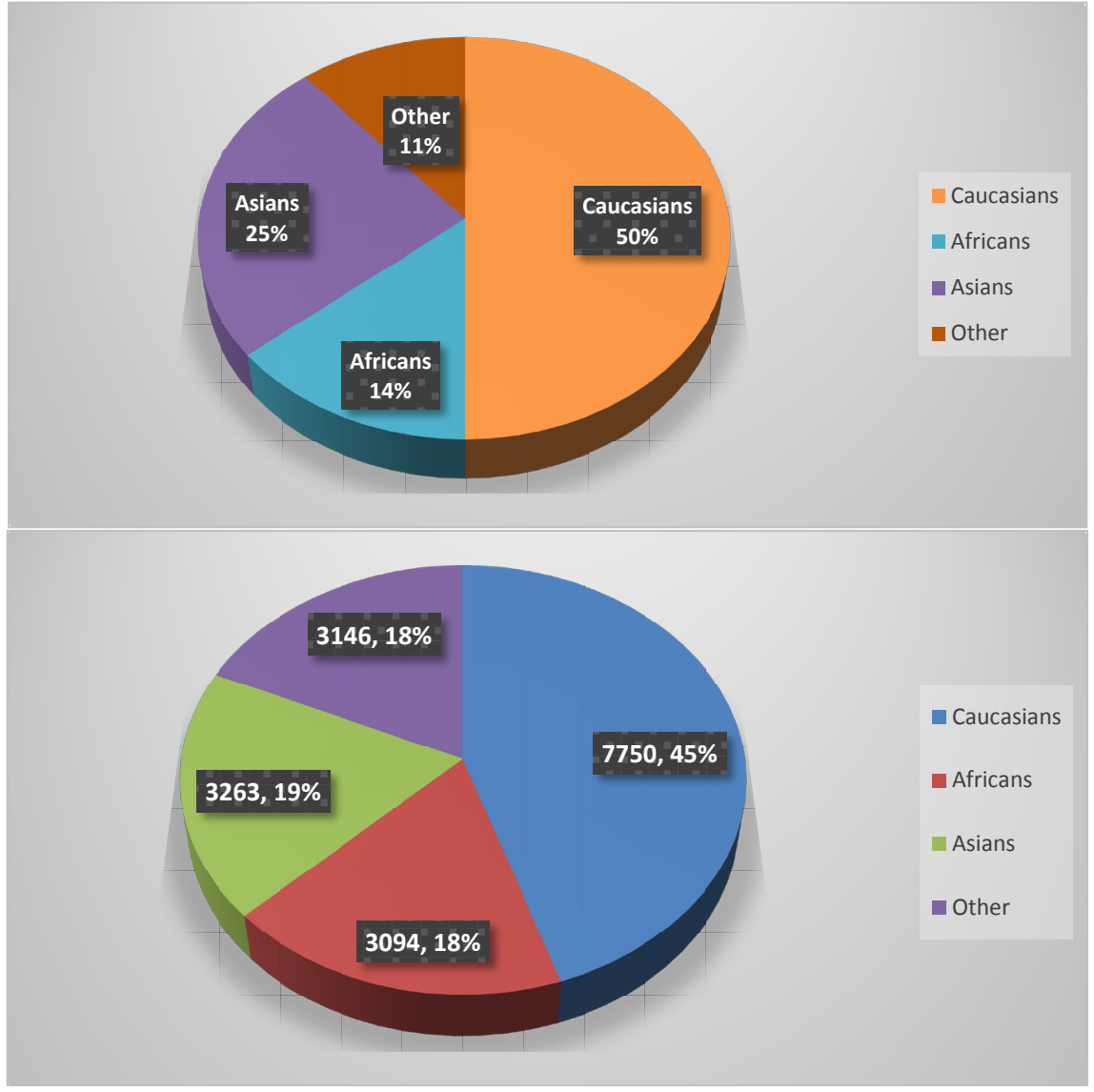




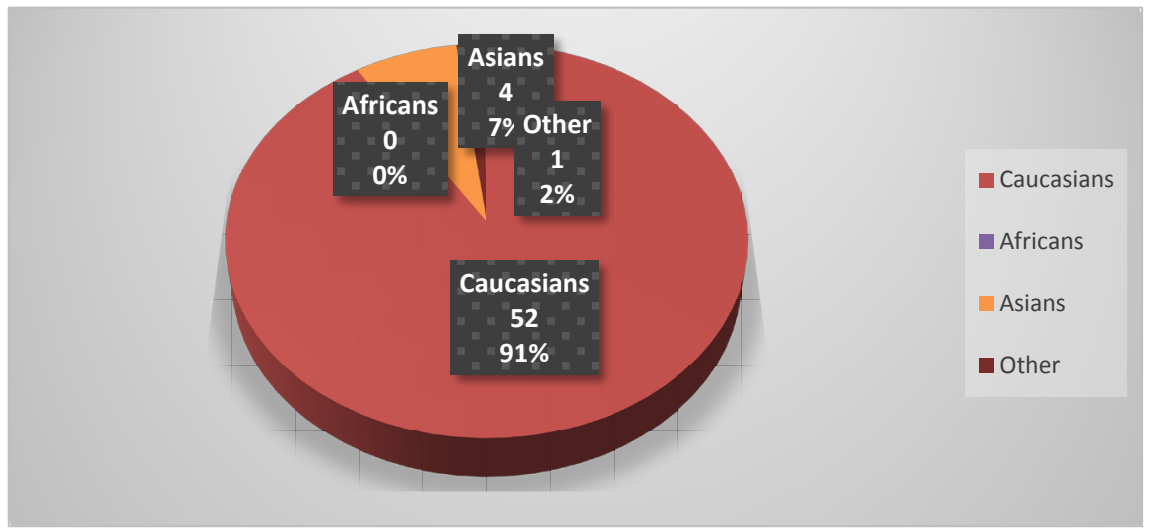

Figure 2. Distribution of reviewed studies (top) cumulative samplesize by category (middle) and CCR5 $\Delta 32$ Homozygotes by category (bottom).

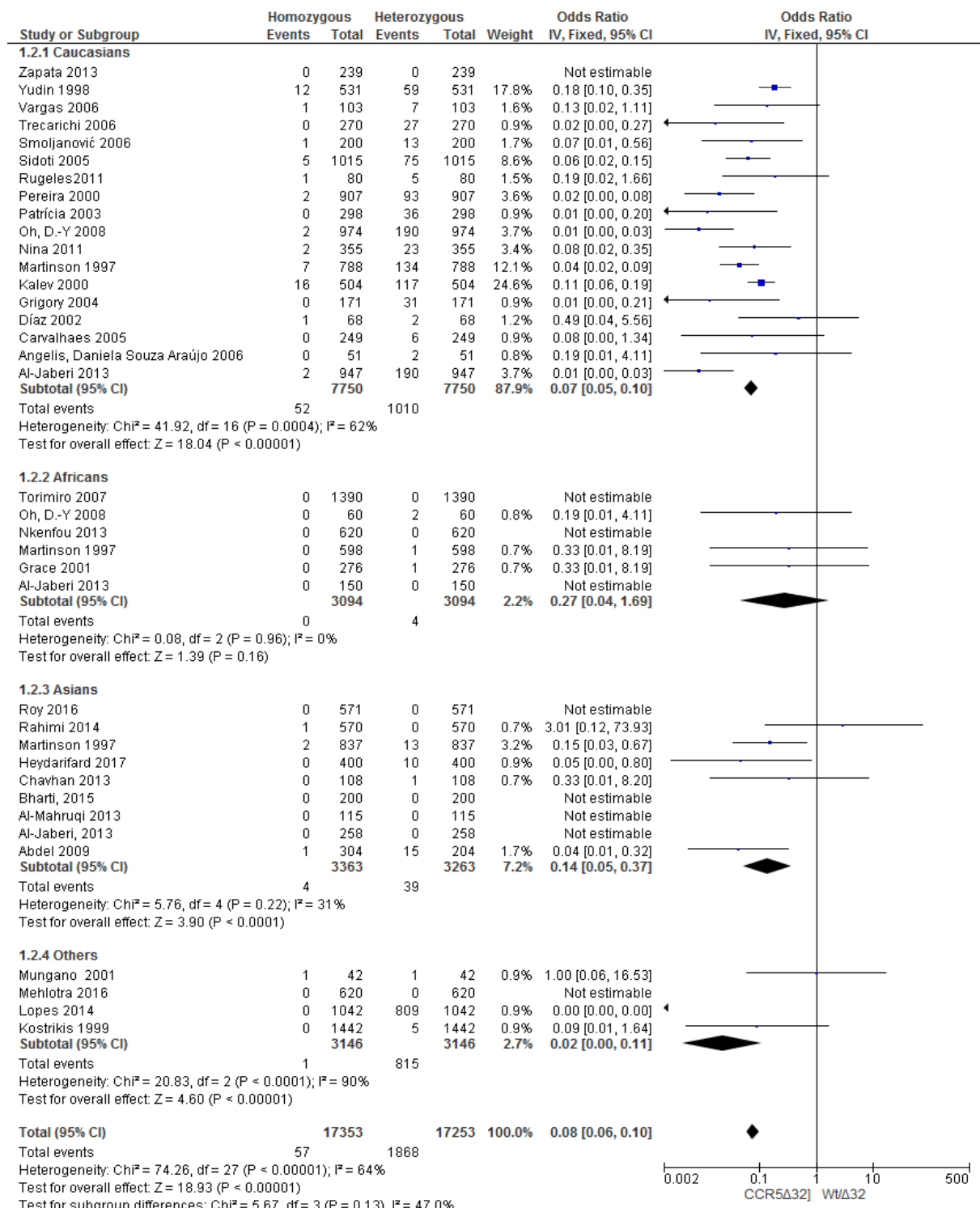

Figure 3. Forest plot comparing the distribution of CCR5 Homozygosity and Heterozygosity among various populations (Caucasians, Asians, Africans and Others). 


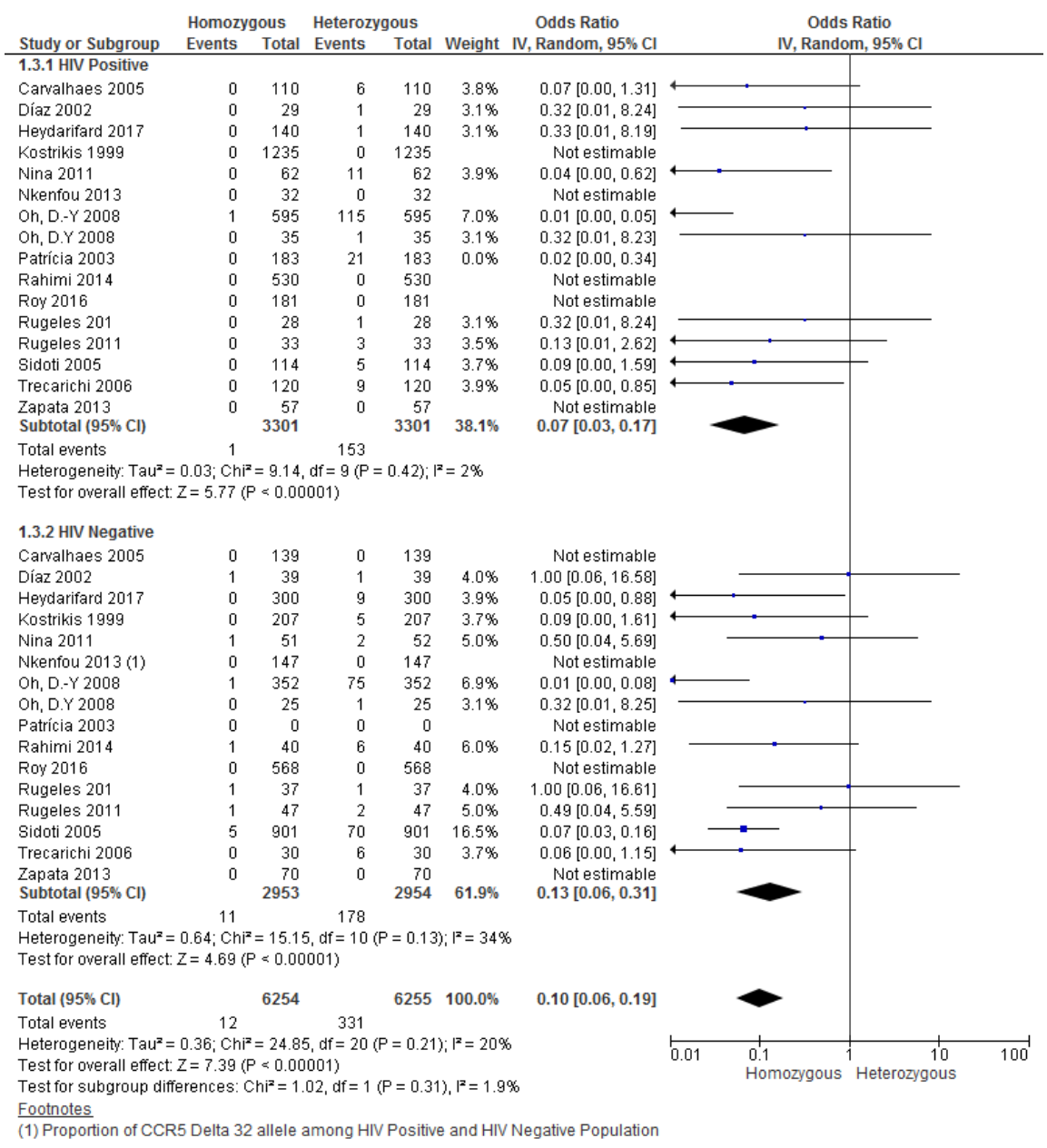

Figure 4. Forest Plot detailing the comparison of CCR5 Homozygosity and Heterozygosity among HIV positive and HIV Negative individual in the reviewed data.

\section{Discussions}

This review correlated data from studies on the distribution of CCR $5 \Delta 32$ which is a natural selection allele acting in humans against HIV/AIDS as demonstrated by previous studies [6]. The result of this meta-analysis involving 37 articles with 17,253 participants from diverse backgrounds sheds great lights on the distribution of this allele globally as well its association with HIV-1 epidemiology. The study undoubtedly demonstrates that there is a wide knowledge gap on CCR5 $\triangle 32$ especially in African where HIV burden is highest but further confirms that CCR5 32 heterozygosity does not protect individuals against HIV-1 infection but rather slows progression of the disease [16] [42].

High concentration of studies on CCR5 $\Delta 32$ is seen among the Caucasians. Globally $50 \%$ of the articles available for review covered this population while only three complete articles from African population were found representing less that $10 \%$. Details from the study equally indicate that there is a likelihood of being homozygous of the allele when a Caucasian than any other race since most CCR5 32 homozygotes were Caucasians. However the few homozygotes seen 
among the Asian group could have been as a result of gene flow [6]. Notably, among African population no one was positive for the allele while in the remaining un-grouped population only one individual was present in Nigeria as recorded by Martison and group in 1997 [6].

There is a possibility that the results in our study may be regionally and racially biased based on the data available online. Language bias, especially on manuscripts published in other languages other than English may also be another factor that could have affected our analysis.

\section{Conclusion}

This meta-analysis is in line with previous various studies and concludes that CCR5 $\triangle 32$ is highly concentered among the Caucasians as compared to other populations. From the systematic review conducted; $91 \%$ of the total number of individuals who were found to be CCR5 homozygous are Caucasians and 50\% of articles available for review were also from that same region. Likewise, results presented here indicate that Caucasians as compared to other populations are less susceptible to HIV virus infection due to the expression rates of CCR5 32 while the rest of the populations experience a much higher prevalence of the disease. However, scanty data experienced is Africa is a clear indication that minimal work has been done in trying to associate the allele and HIV infection in different populations. This study recommends further studies on relevant contextual factors including but not limited to social, economic and nutritional factors given that a lot of cross-border travels and inter-race marriages has occurred over the years. A mixture of population genetics and epidemiological studies can also be explored.

\section{Conflicts of Interest}

The authors declare no conflicts of interest regarding the publication of this paper.

\section{References}

[1] Rottman, J.B., Ganley, K.P., Williams, K., Wu, L., Mackay, C.R. and Ringler, D.J. (1997) Cellular Localization of the Chemokine Receptor CCR5: Correlation to Cellular Targets of HIV-1 Infection. American Journal of Pathology, 151, 1341-1351.

[2] Kawamura, et al. (2003) R5 HIV Productively Infects Langerhans Cells, and Infection Levels Are Regulated by Compound CCR5 Polymorphisms. Proceedings of the National Academy of Sciences of the USA, 100, 8401-8406.

[3] Liu, R., Paxton, W.A., Choe, S., Ceradini, D., Martin, S.R., Horuk, R., et al. (1996) Homozygous Defect in HIV-1 Corrector Accounts for Resistance of Some Multiply-Exposed Individuals to HIV-1 Infection. Cell, 86, 367-377. https://doi.org/10.1016/S0092-8674(00)80110-5

[4] Samson, M., Libert, F., Doranz, B.J., Rucker, J., Liesnard, C., Farber, C.-M., et al. (1996) Resistance to HIV-1 Infection in Caucasian Individuals Bearing Mutantalleles of the CCR-5 Chemokine Receptor Gene. Nature, 382, 722-725. https://doi.org/10.1038/382722a0 
[5] Gupta, A. and Padh, H. (2012) The Global Distribution of CCR5 Delta 32 Polymorphism: Role in HIV-1 Protection. BMC Infectious Diseases, 12, O16. https://doi.org/10.1186/1471-2334-12-S1-O16

[6] Martinson, J.J., Chapman, N.H., Rees, D.C. and Clegg, J.B. (1997) Global Distribution of the CCR5 Gene 32-Basepair Deletion. Nature Genetics, 16, 100-103.

[7] Moher, D., Liberati, A., Tetzlaff, J. and Altman, D.G. (2009) Preferred Reporting Items for Systematic Reviews and Meta-Analyses: The PRISMA Statement. PLoS Medicine [Internet], 6, e1000097. https://doi.org/10.1371/journal.pmed.1000097

[8] Cochran, W.G. (1954) The Combination of Estimates from Different Experiments. Biometrics, 10, 101-129. https://doi.org/10.2307/3001666

[9] Egger, M., Smith, G.D., Schneider, M. and Minder, C. (1997) Bias in Meta-Analysis Detected by a Simple, Graphical Test. BMJ, 315, 29-34.

[10] Oh, D.-Y., Jessen, H., Kücherer, C., Neumann, K., Oh, N., Poggensee, G., et al. (2008) CCR5 $\Delta 32$ Genotypes in a German HIV-1 Seroconverter Cohort and Report of HIV-1 Infection in a CCR5 32 Homozygous Individual. PLoS ONE, 3, e2747. https://doi.org/10.1371/journal.pone.0002747

[11] Al-Mahruqi, S.H., Zadjali, F., Beja-Pereira, A., Koh, C.Y., Balkhair, A. and Al-Jabri, A.A. (2014) Genetic Diversity and Prevalence of CCR2-CCR5 Gene Polymorphisms in the Omani Population. Genetics and Molecular Biology, 37, 7-14.

[12] Trecarichi, E.M., Tumbarello, M., de Gaetano Donati, K., Tamburrini, E., Cauda, R., Brahe, C. and Tiziano, F.D. (2006) Partial Protective Effect of CCR5-Delta 32 Heterozygosity in a Cohort of Heterosexual Italian HIV-1 Exposed Uninfected Individuals. AIDS Research and Therapy, 3, 22.

[13] Smoljanović, M., Ristic, S. and Hayward, C. (2006) Historic Exposure to Plague and Present-day Frequency of CCR5del32 in Two Isolated Island Communities of Dalmatia, Croatia. Croatian Medical Journal, 47, 579-584.

[14] Lopes, M.P., Santos, M.N.N., Faber, E.W., Bezerra, M.A.C., Hatzlhofer, B.L.D., Albuquerque, D.M., et al. (2014) The CCR5 32 Polymorphism in Brazilian Patients with Sickle Cell Disease. Disease Markers, 2014, Article ID: 678246.

[15] Chavhan, A.B., Pawar, S.S., Jadhao, R.G. and Patil, K.G. (2013) Distribution of CC-Chemokine Receptor-5- $\Delta 32$ Allele among the Tribal and Caste Population of Vidarbha Region of Maharashtra State. Indian Journal of Human Genetics, 19, 65-70. https://doi.org/10.4103/0971-6866.112894

[16] Rahimi, H., Farajollahi, M.M. and Hosseini, A. (2014) Distribution of the Mutated Delta 32 Allele of CCR5 Co-Receptor Gene in Iranian Population. Medical Journal of the Islamic Republic of Iran, 28, 140.

[17] Biloglav, Z., et al. (2009) Historic, Demographic, and Genetic Evidence for Increased Population Frequencies of CCR5 $\Delta 32$ Mutation in Croatian Island Isolates after Lethal 15th Century Epidemics. Croatian Medical Journal, 50, 34-42. https://doi.org/10.3325/cmj.2009.50.34

[18] Kostrikis, L.G., et al. (1999) A Polymorphism in the Regulatory Region of the CC-Chemokine Receptor 5 Gene Influences Perinatal Transmission of Human Immunodeficiency Virus Type 1 to African-American Infants. Journal of Virology, 73, 10264-10271.

[19] Nkenfou, C.N., Mekue, L.C.M., Nana, C.T. and Kuiate, J.R. (2013) Distribution of CCR5-Delta32, CCR5 Promoter 59029 A/G, CCR2-64I and SDF1-3'A Genetic Polymorphisms in HIV-1 Infected and Uninfected Patients in the West Region of Cameroon. BMC Research Notes, 6, 288. https://doi.org/10.1186/1756-0500-6-288 
[20] Bharti, D., et al. (2015) Low Prevalence of CCR5- 432 , CCR2-64I and SDF1-3'A Alleles in the Baiga and Gond Tribes of Central India. SpringerPlus, 4, 451. https://doi.org/10.1186/s40064-015-1238-6

[21] Heydarifard, Z., Tabarraei, A. and Moradi, A. (2017) Polymorphisms in CCR5- $\Delta 32$ and Risk of HIV-1 Infection in the Southeast of Caspian Sea, Iran. Disease Markers, 2017, Article ID: 4190107.

[22] Roy, P. and Chakrabarti, S. (2015) Mutation in AIDS Restriction Gene Affecting HIV Infection and Disease Progression in a High Risk Group from Northeastern India. Medical Journal Armed Forces India, 72, 111-115.

[23] Zapata, W., et al. (2013) Influence of CCR5 and CCR2 Genetic Variants in the Resistance/Susceptibility to HIV in Serodiscordant Couples from Colombia. AIDS Research and Human Retroviruses, 29, 1594-1603.

https://doi.org/10.1089/aid.2012.0299

[24] Mehlotra, R.K., et al. (2015) CCR2, CCR5, and CXCL12 Variation and HIV/AIDS in Papua New Guinea. Infection, Genetics and Evolution, 36, 165-173.

[25] de Lima Guerra, A., et al. (2016) Frequency of CCR5 Genotypes in HIV-Infected Patients in Roraima, Brazil. Brazilian Journal of Infectious Diseases, 20, 314-315. https://doi.org/10.1016/j.bjid.2016.01.001

[26] Angelis, D.S., et al. (2007) CCR5 Genotypes and Progression to HIV Disease in Perinatally Infected Children. Brazilian Journal of Infectious Diseases, 11, 196-198. https://doi.org/10.1590/S1413-86702007000200004

[27] Vargas, A.E., Marrero, A.R., Salzano, F.M., Bortolini, M.C. and Chies, J.A.B. (2006) Frequency of CCR5 Delta32 in Brazilian Populations. Brazilian Journal of Medical and Biological Research, 39, 321-325. https://doi.org/10.1590/S0100-879X2006000300002

[28] Munerato, P., et al. (2003) Frequency of Polymorphisms of Genes Coding for HIV-1 Co-Receptors CCR5 and CCR2 in a Brazilian Population. Brazilian Journal of Infectious Diseases, 7, 236-240.

[29] Díaz, F.J., et al. (2000) Frequency of CCR5 Delta-32 Mutation in Human Immunodeficiency Virus (HIV)-Seropositive and HIV-Exposed Seronegative Individuals and in General Population of Medellin, Colombia. Memórias do Instituto Oswaldo Cruz, 95, 237-242. https://doi.org/10.1590/S0074-02762000000200018

[30] Pereira, R.W., et al. (2000) Frequency of the CCR Delta32 Allele in Brazilians: A Study in Colorectal Cancer and in HTLV-I Infection. Genetics and Molecular Biology, 23, 523-526. https://doi.org/10.1590/S1415-47572000000300003

[31] Rugeles, M.T., Velilla, P.A. and Montoya, C.J. (2011) Mechanisms of Human Natural Resistance to HIV: A Summary of Ten Years of Research in the Colombian Population. Biomédica, 31, 269-280.

[32] Valadez-González (2011) Implicación del alelo CCR5- $\Delta 32$ en la progresión clínica de pacientes VIH-1 + en Yucatán, Méxic.

[33] Salem, A.H., et al. (2009) Epidemiology Distribution of Four HIV Type 1-Resistance Polymorphisms (CCR5- 32 , CCR5-m303, CCR2-64I, and SDF1-3'A) in the Bahraini Population. AIDS Research and Human Retroviruses, 25, 973-977.

[34] Yudin, N.S., et al. (1998) Distribution of CCR5-Delta32 Gene Deletion across the Russian Part of Eurasia. Human Genetics, 102, 695-698.

[35] Grigory (2004) Genetic Testing.

[36] John, G.C., et al. (2001) CCR5 Promoter Polymorphisms in a Kenyan Perinatal Human Immunodeficiency Virus Type 1 Cohort: Association with Increased 2-Year 
Maternal Mortality. The Journal of Infectious Diseases, 184, 89-92. https://doi.org/10.1086/321006

[37] Sidoti, A., et al. (2005) Distribution of the Mutated $\Delta 32$ Allele of the CCR5 Gene in a Sicilian Population. International Journal of Immunogenetics, 32, 193-198. https://doi.org/10.1111/j.1744-313X.2005.00507.x

[38] Mangano, A., Theiler, G., Sala, L., Capucchio, M., Fainboim, L. and Sen, L. (2001) Distribution of CCR5- $\Delta 32$ and CCR2-64I Alleles in an Argentine Amerindian Population, Alleles in an Argentine Amerindian Population. Tissue Antigens, 58, 99-102.

http://login.research4life.org/tacsgr1doi_org/10.1034/j.1399-0039.2001.580207.x

[39] Torimiro, J.N., et al. (2004) Frequency of CCR5 Variants among Rural Populations with Low HIV-1 Prevalence in Cameroon. AIDS, 21, 527-528.

[40] Al-Jaberi, S.A., Ben-Salem, S., Messedi, M., Ayadi, F., Al-Gazali, L. and Ali, B.R. (2013) Determination of the CCR5 $\Delta 32$ Frequency in Emiratis and Tunisians and the Screening of the CCR5 Gene for Novel Alleles in Emiratis. Gene, 529, 113-118.

[41] Kalev, I., Mikelsaar, A.-V., Beckman, L., Tasa, G. and Pärlist, P. (2000) High Frequency of the HIV-1 Protective CCR5 $\Delta 32$ Deletion in Native Estonians. European Journal of Epidemiology, 16, 1107-1109. https://doi.org/10.1023/A:1010829816334

[42] Contopoulos-Ioannidis, D.G., et al. (2003) Effect of CCR5-Delta32 Heterozygosity on the Risk of Perinatal HIV-1 Infection: A Meta-Analysis. Journal of Acquired Immune Deficiency Syndromes, 32, 70-76.

https://doi.org/10.1097/00126334-200301010-00010 